\title{
Organomineral Phosphorus Fertilization in the Production of Corn, Soybean and Bean Cultivated in Succession*
}

\author{
Denize Carvalho Martins', Álvaro Vilela De Resende², João Carlos Cardoso Galvão, \\ Eduardo De Paula Simãoํㅜ, José Paulo Da Costa Ferreira3 ${ }^{3}$ Gabriela De Oliveira Almeida ${ }^{3}$ \\ ${ }^{1}$ Department of Plant Science, Federal University of Viçosa, Viçosa, Brazil \\ ${ }^{2}$ Embrapa Maize and Sorghum, Sete Lagoas, Brazil \\ ${ }^{3}$ Federal University of São João Del Rei, Sete Lagoas, Brazil \\ Email: denizecarvalhom@yahoo.com.br, alvaro.resende@embrapa.br, jgalvao@ufv.br, eduardosimao.agro@yahoo.com.br, \\ zepaulo_prados@hotmail.com,gabrielaolivalm@gmail.com
}

How to cite this paper: Martins, D.C., Resende, Á.V., Galvão, J.C.C., Simão, E.P., Ferreira, J.P.C. and Almeida, G.O. (2017) Organomineral Phosphorus Fertilization in the Production of Corn, Soybean and Bean Cultivated in Succession. American Journal of Plant Sciences, 8, 2407-2421. https://doi.org/10.4236/ajps.2017.810163

Received: August 2, 2017

Accepted: September 10, 2017

Published: September 13, 2017

Copyright $\odot 2017$ by authors and Scientific Research Publishing Inc. This work is licensed under the Creative Commons Attribution International License (CC BY 4.0).

http://creativecommons.org/licenses/by/4.0/

(c) $\underset{\mathrm{EY}}{0}$ Open Access

\begin{abstract}
The use of organic waste in agriculture has been used aiming at greater productivity, decrease in the cost of production and sustainable use of resources. The present study aimed at evaluating the effect of phosphate fertilization with the maintenance of organomineral fertilizers, combining poultry manure and soluble or reactive phosphate, in the production of grains in corn culture and the residual effect for subsequent crops of beans and soybeans. The experiment was conducted in Sete Lagoas, MG, in 2015, using three fertilizers with sources of different phosphorus sources (triple super phosphate-STP, organomineral with STP and organomineral with Bayovar phosphate) applied at the doses of $65,130,195$ and $260 \mathrm{~kg} \cdot \mathrm{ha}^{-1}$ of $\mathrm{P}_{2} \mathrm{O}_{5}$ total, and compared to the control without phosphate fertilization. We evaluated the contents of foliar $\mathrm{P}$, $\mathrm{P}$ accumulation in the grains, yields of corn grains, beans and soy, accumulated productivity and export of accumulated $\mathrm{P}$ of the three cultures. The three cultures assessed presented higher productivity when compared to the average of the factorial treatments that received phosphate fertilization relative to the control. Organomineral fertilizers increased grain production, obtaining average productivity equal to or greater than those obtained with the exclusive use of STP.
\end{abstract}

\section{Keywords}

Reactive Phosphate, Poultry Manure, New Fertilizers

${ }^{\star}$ This work is part of the doctoral thesis of the first author. 


\section{Introduction}

Aiming at a sustainable agriculture, it is becoming increasingly necessary to use systems capable of providing greater productivity, and coupled with the efficiency in the supply of nutrients [1]. Often, the productivity of grain in Brazil is limited by high production costs, fertilizers being the more expensive inputs [2] [3].

The use of organic waste in fertilization is an attractive possibility from the economic and environmental point of view. The recycling of nutrients contained in organic matters accessible to the farmer is an alternative to the application of conventional fertilizers of high cost, in addition to minimizing the chance of pollution by incorrect waste disposal generated in agricultural activities [4].

The Brazilian production of broilers in 2015 was 13 million tons [5], generating large amount of waste such as the poultry manure. The main destination of these materials is the agricultural use "in natura", which normally occurs without technical criteria that allow efficient use, resulting in large losses of nutrients [6].

One promising option is the use of organic waste in the production of organomineral fertilizers. According to the normative No. 23 of the Ministry of Agriculture, Livestock and Food Supply, of August 31, 2005, organomineral fertilizer is the product derived from the physical mixture or combination of mineral and organic sources of nutrients. These fertilizers should contain the primary macronutrients $(\mathrm{N}, \mathrm{P}, \mathrm{K})$ or their sum (NP, NK, PK or NPK) in a content of at least $10 \%$. To meet the legislation, one may add sources of phosphorus, nitrogen or potassium to organomineral fertilizers.

In order to meet the grain producing market, Embrapa has developed a technology for production of granular organomineral fertilizers from poultry manure with highest concentration of nutrients, due to low use of these fertilizers for this sector [6].

The Brazilian soils present low natural availability of phosphorus and large amounts of these fertilizers are used containing this nutrient, in order to compensate for the ability to drain the soil, which is a lot larger than that of the plant [7]. Initially, corrective phosphate fertilizations are necessary to raise the availability of $\mathrm{P}$ to a satisfactory level for the appropriate development of cultures. From this stage, maintenance fertilizations are permitted with smaller P maintenance doses sufficient to ensure good yields.

The characteristics of phosphorus sources may influence the agronomic efficacy of fertilization, which is also affected by soil conditions such as the initial level of fertility, the texture, the history of fertilization and crop management. Reactive natural phosphates are phosphorus sources that have intermediate solubility between soluble $\mathrm{P}$ sources (as in the example of triple superphosphate) and the Brazilian rock natural phosphates [8] [9].

It is possible that the incorporation of phosphorus sources to an organic base to obtain organomineral fertilizers modifies its typical behavior in soil, impacting on the efficiency of its utilization by crops. According to Kiehl [10] organo- 
minerals can improve the efficiency of mineral fertilizers and enhance the effects of nutrients, making them more available to plants. In addition, the organic matter presents in the organiminerals form a protection to the minerals, decreasing the loss of nutrients.

The present study was aimed at evaluating the effect of phosphate fertilization with the maintenance of organomineral fertilizers, combining poultry manure and soluble or reactive phosphate, in the production of grains in corn culture and the residual effect for subsequent crops of beans and soybeans, on latosol of the Central Region of Minas Gerais.

\section{Material and Methods}

The experiment was conducted at Embrapa Corn and Sorghum (latitude $19^{\circ} 28^{\prime} 36^{\prime \prime S}$, longitude $44^{\circ} 11^{\prime} 53^{\prime \prime} \mathrm{W}$ and altitude $732 \mathrm{~m}$ ), in Sete Lagoas, MG, The climate, according to Köppen's (1948) classification, is of the Cwa type (dry winter and hot summer), annual average temperature of $21.75^{\circ} \mathrm{C}$ and annual average rain of $1.345 \mathrm{~mm}$.

The soil is classified as very clayey dystrophic Red Latosol (66\%), having already been cultivated and fertilized for several years, and the area was fallow (spontaneous vegetation) for 5 years prior to the implementation of the experiment.

Preceding the installation of the experiment, a scarifier was used $25 \mathrm{~cm}$ deep and the application of 2.5 ton $\cdot \mathrm{ha}^{-1}$ of lime and 2 ton.ha ${ }^{-1}$ of agricultural plaster was used, both embedded with both plowing grid. Then there were applied 200 $\mathrm{kg} \cdot \mathrm{ha}^{-1}$ mixture of potassium chloride and FTE BR 12 at a ratio of 3:1, ending with a harrowing leveler.

Fertility conditions in the $0-20 \mathrm{~cm}$ layer of depth, before the installation of the experiment were: $\mathrm{pH}$ in water 5.9; organic matter $3.6 \mathrm{dag} \cdot \mathrm{kg}^{-1}$; contents of $\mathrm{P}$ and $\mathrm{K}$ (Mehlich 1) of 6 and $105 \mathrm{mg} \cdot \mathrm{dm}^{-3}$, respectively; $\mathrm{Ca}, \mathrm{Mg}, \mathrm{Al}, \mathrm{H}+\mathrm{Al}$ and CTC potential of 4.4, 0.8, 0.0, 4.3, and $9.8 \mathrm{cmolc} \cdot \mathrm{dm}^{-3}$, respectively; and saturation by bases $(\mathrm{V} \%)$ of $53 \%$.

Organomineral phosphate fertilizers were produced from physical processes for drying and grinding for particle size reduction of the residues of poultry manure, being added in the process the sources of phosphorus and other nutrients to achieve the desirable organomineral fertilizers.

The experimental delimitation used was casual blocks, in factorial scheme $3 \times$ $4+1$, with four blocks. The first factor corresponded to three sources of phosphorus: triple superphosphate (STP, with $44 \%$ of $\mathrm{P}_{2} \mathrm{O}_{5}$ total); OBAY, organomineral based on poultry manure with reactive Bayovar phosphate $(16.3 \%$ of total $\mathrm{P}_{2} \mathrm{O}_{5}$ total) and OSTP, organomineral with super triple (13.4\% of total $\mathrm{P}_{2} \mathrm{O}_{5}$ ). The second factor consisted of doses of 65, 130, 195 and $260 \mathrm{~kg} \cdot \mathrm{ha}^{-1}$ of $\mathrm{P}_{2} \mathrm{O}_{5}$ total As additional treatment, a control without phosphate fertilization was used.

The treatments consisted of maintenance phosphate fertilization for corn culture, being the residual effect evaluated in subsequent crops of beans and soy. 
For application of the treatments, the quantities of $\mathrm{P}$ sources were distributed manually on the plots, in grooves spaced $50 \mathrm{~cm}$, open with tractor implement. After covering the compost with a thin layer of soil, corn seeds were deposited by hand and covered with another layer of soil. The sowing of the corn (DKB 390 PRO) was held in the first half of January 2015.

The crops which came afterwards were established at the same spacing between lines of plants without soil tickler, using mechanized seeder with lines overlapping the location of deposition of corn phosphate fertilization. Thereby, the beans (BRS Style) were seeded in the second fortnight of July and the soybeans (BRS 7780 IPRO) in the second half of November 2015. The density of the plants was 60,000, 290,000 and 300,000 for corn, beans and soybeans, respectively. In all cultures, each plot was made up of four lines of seven meters long, considering as useful area the two centerlines, discarding one meter surrounding at the ends.

Fertilizing in coverage for the supply of $\mathrm{N}$ and/or $\mathrm{K}$ was made manually, beside the lines of crops, with no incorporation. Corn received $200 \mathrm{~kg} \cdot \mathrm{ha}^{-1}$ of urea at 19 days after sowing (DAS) and at 27 DAS, plus $300 \mathrm{~kg} \cdot \mathrm{ha}^{-1}$ of NPK formulate 20-00-20. For the beans, two fertilizations were held, the first at 26 DAS with 200 $\mathrm{kg} \cdot \mathrm{ha}^{-1}$ of NPK $20-00-20$ and the second at 40 DAS with $200 \mathrm{~kg} \cdot \mathrm{ha}^{-1}$ of ammonium sulfate. Soybeans received inoculation with rhizobium and the fertilization was held at 17 DAS with $100 \mathrm{~kg} \cdot \mathrm{ha}^{-1}$ of $\mathrm{K}_{2} \mathrm{O}$, in the form of potassium chloride.

In all crops, supplementary irrigation was used through conventional spraying. The control of weeds, pests and diseases was made whenever necessary, by means of constant monitoring.

Among the reviews of the experiment, soil sampling was made at the beginning of the cycle of corn (at 26 DAS), collecting with auger samples in lines and in between lines of fertilization in each plot, at a depth of $0-10 \mathrm{~cm}$. The samples sent to the laboratory were composed by five simple samples and analyzed as to the contents of $\mathrm{P}$ available by extractors Mehlich 1 and by Ion Exchange Resin, as per methodologies described by Silva [11].

At the flowering of each of the three cultures, samples were collected for the determination of the contents of phosphorus, as per methodologies described by Malavolta [12]. For the corn crop, leaves were collected, which were located below and in a position opposite to the spike being used the middle third without rib, of 6 plants, taken at random, per plot. For the beans, leaves were collected from the median third of 10 plants. In soybeans, it was collected the third trifoliate (with petiole) from the apex in 12 plants per plot. After the samplings, the leaves were cleaned with paper towels and packed in paper bags. Subsequently, the material was dried, ground and analyzed for phosphorus content in the leaves.

The harvest was carried out manually in the useful area of the lots. Moisture and weight of the grains were established, correcting the productivity to $13 \%$ moisture. Grain samples were dried in an oven with forced air circulation at $60^{\circ} \mathrm{C}-70^{\circ} \mathrm{C}$ until reaching constant mass, and analyzed as to the content of $\mathrm{P}$ as 
per Malavolta et al. [12]. It was determined in grain nutrient buildup, corresponding to the export in each treatment.

The data were subjected to variance analysis and, when there were significant differences in function of the treatments (F test), Tukey test was applied or a regression analysis was conducted, with the assistance of SISVAR statistical program [13].

\section{Results and Discussion}

P contents available in the soil at the initial phase of the cycle of corn (26 DAS), determined with ion exchange resin and by the Mehlich 1 Extractor, were influenced by the doses of the nutrient in the lines of planting (Table 1, Figure 1). The availability of $\mathrm{P}$ in between the lines was not influenced by the treatments, fact already expected due to the low mobility of this nutrient in the soil.

There was linear increment of the availability in the line of plants with the increase of the doses of phosphorus (Figure 1). The values determined with extraction using ion exchange resin and the Mehlich 1 solution had been similar for the lesser doses of $\mathrm{P}_{2} \mathrm{O}_{5}$. In the highest doses (195 and $260 \mathrm{~kg} \cdot h \mathrm{~h}^{-1}$ of $\mathrm{P}_{2} \mathrm{O}_{5}$ ), the Mehlich 1 solution extracted greater amounts of the nutrient. These differences in extraction rates of $\mathrm{P}$ between extraction methods can be attributed to the chemical characteristics of the extractors [14].

There was difference between the sources regarding the Mehlich $1 \mathrm{P}$, but not in relation to the $\mathrm{P}$ resin (Table 1). In the average of the doses provided, organomineral

Table 1. Summary of the variance analysis for phosphorus contents available (P Mehlich and $\mathrm{P}$ Resin) in the soil, in the lines and between lines of planting, and foliar phosphorus contents (PF) in crops of corn, beans and soy, as a function of the fertilizer and dose of fertilizers used.

\begin{tabular}{|c|c|c|c|c|c|c|c|c|}
\hline \multirow{3}{*}{ Source } & \multirow{3}{*}{$\mathrm{DF}$} & \multicolumn{7}{|c|}{ Average square } \\
\hline & & \multicolumn{2}{|c|}{ Line } & \multicolumn{2}{|c|}{ Between line } & \multirow{2}{*}{ PF Corn } & \multirow{2}{*}{ PF Bean } & \multirow{2}{*}{ PF Soy } \\
\hline & & P Mehlich & P Resin & P Mehlich & P Resin & & & \\
\hline Fertilizer (F) & 2 & $53,298.0^{* *}$ & 1614.2 & 3.7 & 3.2 & 0.1 & 0.0 & 0.3 \\
\hline Dose (D) & 3 & $73,455.7^{\star *}$ & $18,337.9^{\star *}$ & 0.9 & 7.4 & $0.3^{\star *}$ & 0.1 & 0.3 \\
\hline $\mathrm{F}^{\star} \mathrm{D}$ & 6 & $11,644.1$ & 1745.8 & 2.8 & 25.3 & $0.1^{*}$ & 0.0 & 0.0 \\
\hline Fat $^{*}$ Add & 1 & $72,654.4^{\star *}$ & $38,778.1^{* *}$ & $16.4^{\star}$ & 0.0 & $0.4^{\star *}$ & 0.3 & $4.0^{\star *}$ \\
\hline Treat & 12 & $39,123.5^{\star *}$ & $8957.9^{\star *}$ & 3.6 & 15.0 & $0.2^{\star *}$ & 0.1 & $0.48^{\star *}$ \\
\hline Block & 3 & 3454.6 & 1162.4 & $9.8^{*}$ & 9.6 & $0.2^{\star}$ & 0.0 & 0.0 \\
\hline Error & 36 & 7431.0 & 1322.3 & 2.5 & 32.4 & 0.0 & 0.1 & 0.1 \\
\hline Total & 51 & & & & & & & \\
\hline C.V. (\%) & & 63.5 & 32.6 & 20.5 & 23.0 & 7.9 & 11.6 & 10.8 \\
\hline Average & & 135.7 & 111.5 & 7.8 & 23.0 & 2.8 & 3.0 & 3.1 \\
\hline
\end{tabular}

${ }^{* *}$ significant at $1 \%$; ${ }^{*}$ significant at $5 \%$ by test $\mathrm{F}$. 


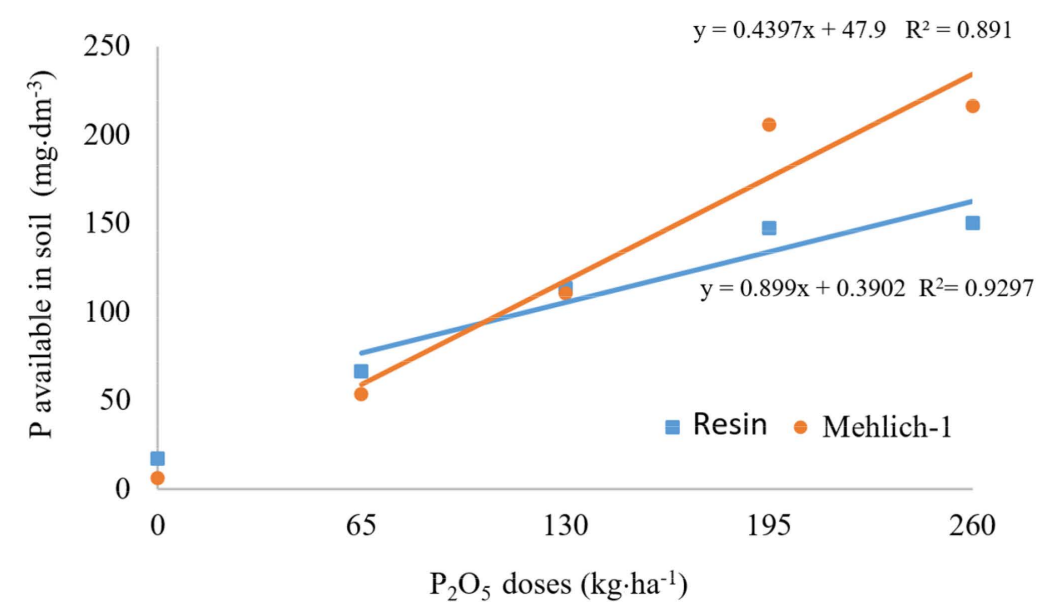

Figure 1. Levels of $\mathrm{P}$ available in soil by Resin and extractors Mehlich 1, in samples collected in the $0-10 \mathrm{~cm}$ depth, in line with increasing doses of the nutrient composted, to 26 days after the sowing of corn (averages of three sources used).

treatment containing reactive phosphate (OBAY) presented value of $211 \mathrm{mg} \cdot \mathrm{dm}^{-3}$ of P Mehlich 1 analysis, surpassing significantly the contents of 101 and 127 $\mathrm{mg} \cdot \mathrm{dm}^{-3}$ quantified in treatments with the super triple soluble phosphate applied pure (STP) or added to source organomineral the (OSTP), respectively, which probably results from the characteristic of this method of analysis, to overestimate the levels of $\mathrm{P}$ available in soils fertilized with natural phosphates, as in the case of the treatment that it received the reactive phosphate of Bayóvar in one of the evaluated sources.

The application of reactive natural phosphates generates the possibility of excessive dissolution of phosphorus by acid extractors, which react preferentially with forms of phosphorus bound to calcium, resulting in a low relation with the absorption by the plants. Ion exchange resin has properties that allow the quantification of the labile phosphorus only [15] [16].

In general, the results of availability of $\mathrm{P}$ in the soil, depending on the fertilization treatments and extractors used in this work, are also consistent with findings of other studies. Evaluating the agronomic efficacy of phosphates in soil with high exchangeable calcium content, Souza et al. [17] found higher contents of $\mathrm{P}$ available when using the Bayóvar phosphate in relation to triple superphosphate. In study performed by Gatiboni et al. [18] for quantification of available phosphorus with different extractors in red distropheric Latosol, too clayey, it was found that the resin method had greater extraction capacity of $\mathrm{P}$ in the treatments with low phosphorus availability, while Mehlich 1 showed the highest extraction capacity under conditions of high nutrient availability.

Only for the culture of corn, foliar phosphorus content reflected significant interaction between the sources and the doses used. The crop of soy presented $\mathrm{P}$ values greater than the average of the factorial (sources $\times$ doses) compared to the control (Table 1). 
In the development of the interaction in corn (Figure 2), there was no adjustment of models of response to doses of STP and OBAY sources. Although one has detected a quadratic response for the OSTP source, the regression curve is hardly enlightening. This apparent inconsistency of foliar contents of $\mathrm{P}$ against the treatments reveals, in fact, little influence of phosphate fertilization on the behavior of the corn under conditions of soil already cultivated and previously fertilized. All values of foliar $\mathrm{P}$ in treatments with or without phosphate fertilization (Figure 2) are within the range of 2.50 to $3.50 \mathrm{~g} \cdot \mathrm{kg}^{-1}$, deemed appropriate for the culture according to Malavolta et al. [12]. The fact that the control treatment also presenting foliar P content $\left(2.63 \mathrm{~g} \cdot \mathrm{kg}^{-1}\right)$ in the proper range can be explained by the availability of the nutrient in the soil, before the implementation of the experiment $\left(6 \mathrm{mg} \cdot \mathrm{dm}^{-3}\right.$, Mehlich 1 extractor), being already at a relatively satisfactory level for the production of grain, as per the interpretation suggested by Sousa and Lobato [19] for very clayish soil.

The low impact of phosphate fertilization on corn on foliar P levels in this study reveals that the history of fertility management can have great influence on potential short-term response to new applications in clay soils of the Cerrado region. By all indications, since this is a very old land culture, the basic level of availability of $P$ in the experimental area and the contribution of other compartments of the nutrient eventually not captured in the analysis of the soil prevented the clear expression of effects of the treatments. Thus, even in the case of a recent fertilization located in the groove of the sowing, with sources that in principle could have a distinct behavior, and provided in contrasting dosages, the previous condition of fertility built end up by masking the answers usually expected.

In this sense, the results obtained differ from literature reports. For example, Frandoloso et al. [9], upon evaluating the efficiency of phosphate fertilizers on corn culture, it was observed average foliar P content of $2.7 \mathrm{~g} \cdot \mathrm{kg}^{-1}$ with the application of triple superphosphate and $2.4 \mathrm{~g} \cdot \mathrm{kg}^{-1}$ with the use of reactive natural phosphate of Gafsa. Ourives et al. [20] reported that the organic fertilizer Bokashi
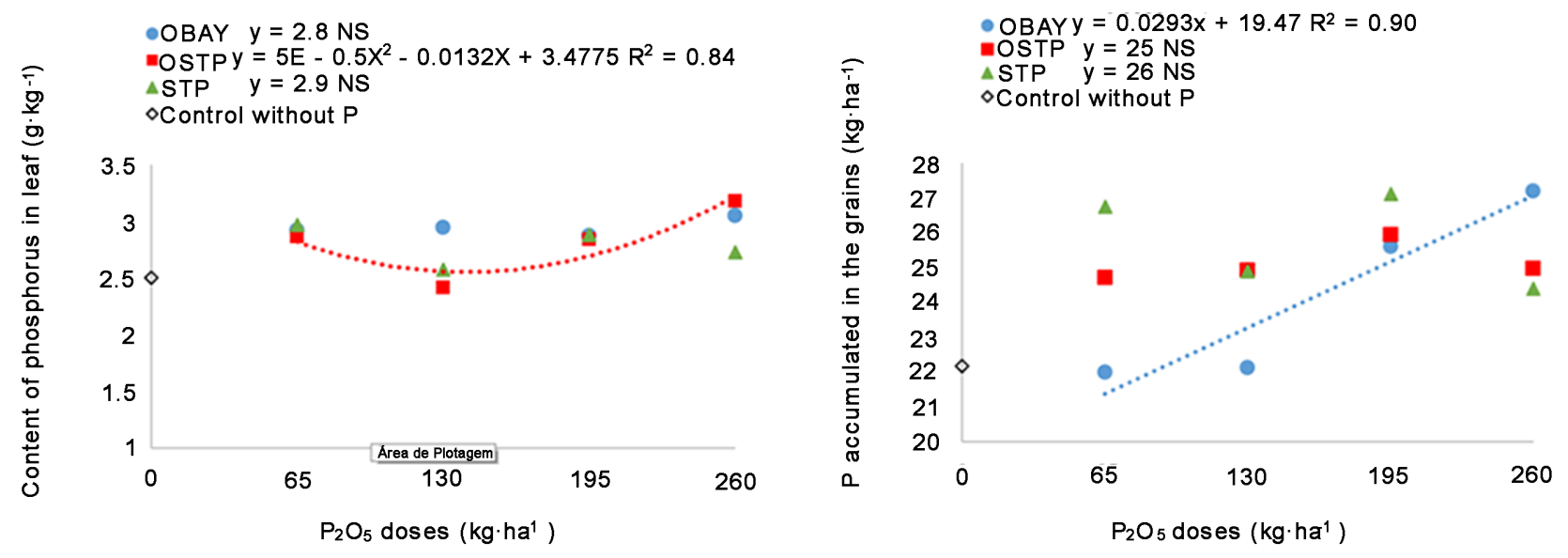

Figure 2. Foliar contents and accumulation of phosphorous in corn grain as a result of doses of the sources used. 
with very rich composition in organic matter promoted mineralization of organic matter and lower phosphorus fixation, making it more available to plants as compared to chemical fertilizer.

In the subsequent cultivation of beans, the foliar phosphorus content for the average fertilization treatments of factorial was $3.02 \mathrm{~g} \cdot \mathrm{kg}^{-1}$, while the control treatment showed $2.75 \mathrm{~g} \cdot \mathrm{kg}^{-1}$ content. Both values are in the range of sufficiency for the culture, which according to Ambrosano et al. [21] is of 2.5 to $4.0 \mathrm{~g} \cdot \mathrm{kg}^{-1}$.

In the third crop, with soy over the residual phosphate fertilization provided initially, foliar P contents were 3.22 and $2.17 \mathrm{~g} \cdot \mathrm{kg}^{-1}$ for the average of factorial treatments and control treatment, respectively. In this case, the control without fertilization was below of the range of sufficiency of 2.5 to $5.0 \mathrm{~g} \cdot \mathrm{kg}^{-1}$ for the culture of soy [22].

Foliar analysis data show that the phosphorus applied in corn culture, independent of the source and even in the smallest doses, was enough to cover the development of subsequent crops. Assuming an initial condition of soil with adequate availability and considering that the demand by plants is not high, the three crops carried out after the phosphate fertilization haven't yet identified major differences among the treatments. In addition, part of the $\mathrm{P}$ absorbed by plants is retained in the fodder, being stored in organic forms, which may contribute to the supply of the nutrient for the subsequent crops [1].

All cultures showed higher productivity for the average factorial with fertilization relative to the control (Table 2). Just bean culture presented differences in productivity because of the type of fertilizer and at doses of phosphorus, but without significant interaction of these factors.

Table 2. Summary of the variance analyses for productivity (Prod.), phosphorus accumulation in grains (PG) in crops of corn, beans and soy, accumulated productivity and accumulated export (Exp.) of $\mathrm{P}$, as a function of the fertilizer and dose of fertilizers used.

\begin{tabular}{|c|c|c|c|c|c|c|c|c|c|}
\hline \multirow{3}{*}{ Source } & \multirow{3}{*}{$\mathrm{DF}$} & \multicolumn{6}{|c|}{ Average square } & & \\
\hline & & \multicolumn{2}{|r|}{ Corn } & \multicolumn{2}{|c|}{ Beans } & \multicolumn{2}{|c|}{ Soybean } & \multicolumn{2}{|c|}{ Accumulated } \\
\hline & & PG & Prod. & PG & Prod. & PG & Prod. & Prod. & Exp. \\
\hline Fertilizer $(F)$ & 2 & 9.8 & $409,852.3$ & $68.3^{* *}$ & $2,631,192.7^{\star *}$ & 5.2 & $120,427.4$ & $4,240,846.1$ & $129.6^{*}$ \\
\hline Dose (D) & 3 & 12.3 & $956,441.0$ & $27.6^{* *}$ & $873,029.6^{*}$ & 14.2 & $129,914.2$ & $2,127,728.3$ & $121.0^{* *}$ \\
\hline $\mathrm{F}^{\star} \mathrm{D}$ & 6 & $11.4^{*}$ & $1,066,072.8$ & 1.8 & $35,219.6$ & 2.2 & $57,230.3$ & $1,115,161.0$ & 19.7 \\
\hline Fat* Adic & 1 & $30.3^{*}$ & $13,051,373.6^{\star *}$ & $112.7^{\star *}$ & $6,948,547.9^{\star *}$ & $97.6^{* *}$ & $1,666,036.1^{\star *}$ & $56,842,999.9^{* *}$ & $676.5^{\star *}$ \\
\hline Trat & 12 & $12.9^{*}$ & $1,928,069.8^{*}$ & $28.6^{* *}$ & $1,253,445.0^{\star *}$ & $13.7^{\star}$ & $220,001.3$ & $6,533,236.9^{* *}$ & $118.1^{* *}$ \\
\hline Block & 3 & $18.6^{*}$ & $1,269,718.5$ & 9.2 & $191,643.5$ & 9.7 & $126,374.6$ & $747,322.9$ & 14.5 \\
\hline Error & 36 & 4.7 & $718,442.5$ & 5.0 & $226,751.3$ & 5.8 & $122,798.3$ & $1,555,601.4$ & 24.8 \\
\hline Total & 51 & & & & & & & & \\
\hline C.V. (\%) & & 8.77 & 6.56 & 21.24 & 17.77 & 15.07 & 12.42 & 6.77 & 9.70 \\
\hline Average & & 24.8 & $12,924.8$ & 10.5 & 2679.5 & 16.0 & 2821.8 & $18,426.6$ & 51.4 \\
\hline
\end{tabular}

${ }^{* *}$ significant at $1 \%$; ${ }^{*}$ significant at $5 \%$ by $\mathrm{F}$ test. 
For corn, the average productivity of grain of factorial treatments was 13,069 $\mathrm{kg} \cdot \mathrm{ha}^{-1}$, with $1880 \mathrm{~kg} \cdot \mathrm{ha}^{-1}$ increment compared to the control treatment without phosphate fertilization. This result reinforces the need and importance of maintenance fertilization for corn, even when the initial availability of $\mathrm{P}$ is interpreted as appropriate, although there was no significant effect of increasing doses of $\mathrm{P}$ nor differences between the sources studied. Thus, one can infer that, for greater safety and stability of production, the scaling of maintenance fertilization on soil of good fertility must be good essential criteria to ensure at least the replacement of the phosphorus that is exported with the harvesting of the grain.

The bean plant nourished from the residual effect of the treatments had increased productivity linearly with increasing doses of $\mathrm{P}$ that had been applied to the first corn crop (Figure 3). Higher average productivity was obtained when using the OSTP fertilizer (Table 3). On average of the factorial, $2785 \mathrm{~kg} \cdot \mathrm{ha}^{-1}$ of grain, representing a significant gain of $1372 \mathrm{~kg} \cdot \mathrm{ha}^{-1}$ compared to the yield provided by the control treatment.

For the third culture, with soy, there was a statistically significant addition of $672 \mathrm{ha}^{-1}$ in the average productivity of the treatments that received phosphate fertilization $\left(2873 \mathrm{~kg} \cdot \mathrm{ha}^{-1}\right)$ in relation to the control $\left(2201 \mathrm{~kg} \cdot \mathrm{ha}^{-1}\right)$. The average productivity of 13,069 $\mathrm{kg} \cdot \mathrm{ha}^{-1}$ of corn, $2785 \mathrm{~kg} \cdot \mathrm{ha}^{-1}$ of beans and $2873 \mathrm{~kg} \cdot \mathrm{ha}^{-1}$ of soy, in the treatments that received phosphate fertilization, were superior to the averages of these cultures in the state of Minas Gerais [23], which corresponded to 5373,1512 and $2658 \mathrm{~kg} \cdot \mathrm{ha}^{-1}$ in agricultural year 2014/2015.

The fact only beans present different productivity gains in function of sources and doses of $\mathrm{P}$ can be connected to this culture having been sown soon after the corn crop, possibly being more benefitted than the soy culture. Ramos et al. [24] evaluating the influence of forage grasses and sources of phosphorus in the production of bean reported that the acids from decomposition of fodder of grass planted previously to the beans probably influenced the increase of $\mathrm{P}$ in the plant and the largest bean production.

The accumulated grain productivity of the three crops was significantly higher in factorial average relative to the control without phosphate fertilization; however,
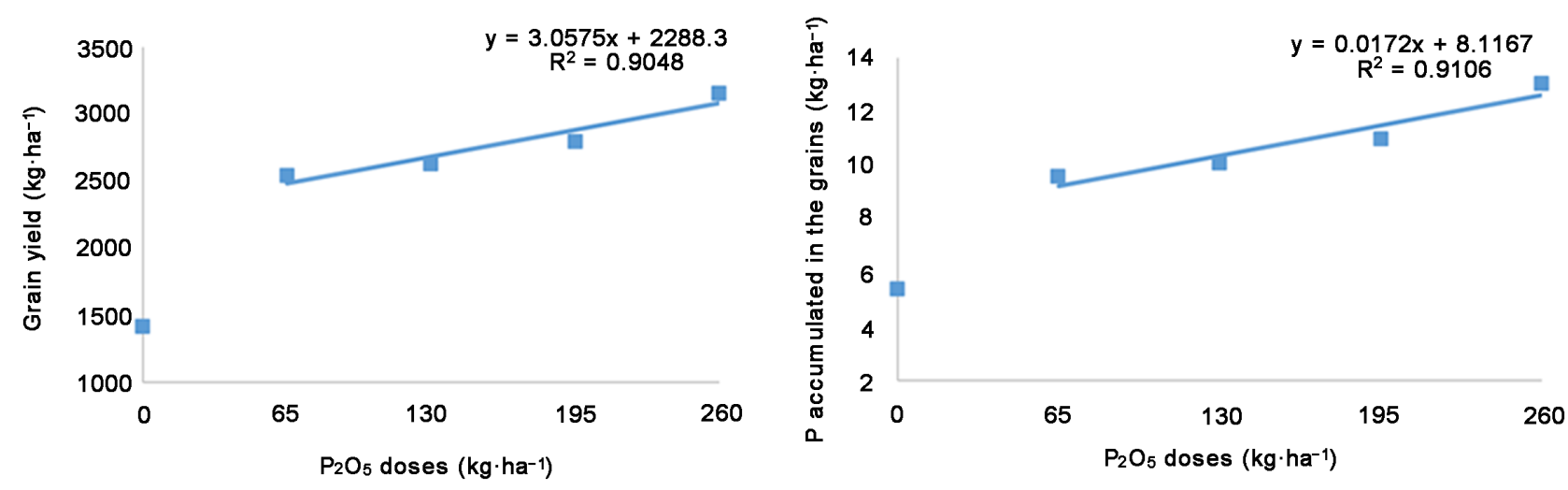

Figure 3. Productivity and phosphorus accumulation in grains of beans as a result of doses of the nutrient applied to the initial cultivation of corn (averages of three sources used). 
Table 3. Productivity and phosphorus accumulation in grains of beans on the basis of the sources used in the first fertilization cultivation with corn.

\begin{tabular}{ccc}
\hline \multirow{2}{*}{ Fertilizers } & \multicolumn{2}{c}{ Beans } \\
\cline { 2 - 3 } & Productivity $\left(\mathrm{kg}^{\mathrm{h}} \mathrm{ha}^{-1}\right)$ & P accumulated grains $\left(\mathrm{kg} \cdot \mathrm{ha}^{-1}\right)$ \\
\hline OBAY & $2448 \mathrm{~b}$ & $9.48 \mathrm{~b}$ \\
STP & $2671 \mathrm{~b}$ & $9.99 \mathrm{~b}$ \\
OSTP & $3235 \mathrm{a}$ & $13.29 \mathrm{a}$ \\
\hline
\end{tabular}

Averages followed by same letters in columns do not differ between themselves, but rather by Tukey test at $5 \%$.

it was not possible to confirm effects of sources and doses, as well as their interaction (Table 2). These results allow stating that, under the conditions of this study, the technical performance of organomineral fertilizers was similar to that of the standard source of triple superphosphate, which corroborates other cases reported in the literature. Borges et al. [25], evaluating efficiency of fertilization with organomineral fertilizer (residue of fridge and poultry manure) in the productivity of soy and corn, reported that when using mineral fertilization, corn productivity was similar to that of the organomineral treatments. Tiritan et al. [26], found that organomineral fertilization proved to be a viable alternative to total or partial replacement for conventional mineral fertilization in corn culture.

In a manner consistent with the answers in productivity, the amount of phosphorus accumulated in grain was superior to the average of the factorial relative to the control in the three crops evaluated (Table 2).

There was no linear effect on the amount of phosphorus accumulated in corn grain according to the doses of $\mathrm{P}_{2} \mathrm{O}_{5}$ when using fertilizer OBAY (Figure 2), which was not the case for sources STP and OSTP. This difference can be attributed to the characteristics of reactive phosphates having not released promptly all $\mathrm{P}$ contained [7], which would entail some limitation of the absorption and subsequent direction to the grains of the nutrient provided in smaller doses. Nevertheless, the productivity was not influenced and, therefore increasing accumulation with increasing doses of OBAY is due to the preferred drain of the nutrient that represent in the corn plant. The accumulation of $\mathrm{P}$ in grains ranged from 22.0 to $27.1 \mathrm{~kg} \cdot \mathrm{ha}^{-1}$ among treatments, amplitude consistent with the data presented by Lacerda et al. [27], which found average value of $23.3 \mathrm{~kg} \cdot \mathrm{ha}^{-1}$ of $\mathrm{P}$ accumulated in corn grains cultivated on soil fertility built in the region of Unaí-MG.

The $\mathrm{P}$ accumulated in the bean grains increased linearly with the increase of the doses of $\mathrm{P}_{2} \mathrm{O}_{5}$ (Figure 3). Higher accumulations were obtained when fertilizer OSTP with 13.3 was used $\mathrm{kg} \cdot \mathrm{ha}^{-1}$ was used (Table 3). Clearly, the accumulation of $\mathrm{P}$ in the grains kept narrow relation with the answers in productivity of the bean plant, indicating that the contents in the grains were relatively constant being the determinative productivity variations of the accumulation differences, which oscillated of 5.39 to $15.59 \mathrm{~kg} \cdot \mathrm{ha}^{-1}$. Carvalho et al. [28], studying nutrient 
accumulation in common bean grains in direct seeding under water deficit, obtained an accumulation of $\mathrm{P}$ in grains between 8.2 to $10.76 \mathrm{~kg} \cdot \mathrm{ha}^{-1}$ in the second year of cultivation of beans.

A possible explanation for the superiority of the residual effect of OSTP may be connected to higher solubility of the super triple and benefits conditioned in addition by the organic portion of the organomineral fertilizer. Organic matter protects the solubilized phosphorus from the fertilizer, inhibiting the reactions of fixation of the element with iron oxides and aluminum present in soils [26]. Thus, the advantage of greater solubility of super triple phosphorus would remain preserved longer after application, favoring its use by crops in succession.

In soybeans, the accumulation of $\mathrm{P}$ in grains was 16.5 and $11.3 \mathrm{~kg} \cdot \mathrm{ha}^{-1}$ for the average of the factorial and control treatments, respectively. The magnitude observed in the experiment was 11.3 to $18.9 \mathrm{~kg} \cdot \mathrm{ha}^{-1}$, with a tendency of the largest doses with the OSTP fertilizer favoring nutrient accumulation in grains. These values are below those found for Lacerda et al. [27] in soybeans, in a system of annual alternance with corn $\left(21.8 \mathrm{~kg} \cdot \mathrm{ha}^{-1}\right.$ for average productivity of 3475 $\left.\mathrm{kg} \cdot \mathrm{ha}^{-1}\right)$.

The sum of the accumulation in the grains in each crop indicates export of phosphorus by the succession of three cultures. This total exportation was bigger for the average of the factorial in relation to the control, having still an isolated effect of the fertilizing factors and doses (Table 2). The exportation increased linearly with the doses of $\mathrm{P}_{2} \mathrm{O}_{5}$ applied, reaching $56.6 \mathrm{~kg} \cdot \mathrm{ha}^{-1}$ of $\mathrm{P}$ at the biggest dose, while in the control treatment the removal with the harvests was 38.9 $\mathrm{kg} \cdot \mathrm{ha}^{-1}$ of P. The use of sources STP and OSTP, consisting of phosphate of bigger solubility, conditioned higher levels of exportation (52.6 and $55.2 \mathrm{~kg} \cdot \mathrm{ha}^{-1}$, respectively) in comparison the OBAY $\left(49.5 \mathrm{~kg} \cdot \mathrm{ha}^{-1}\right)$ that contains reactive phosphate Bayóvar, less soluble.

The total export data by the three crops in succession give indications that there were variations in the amounts of phosphorus absorbed as per the various treatments, which, however, are not reflected in the same way in the accumulated productivity. The use of supplementary irrigation in the experiment certainly mitigates any differences relating to nutritional factors, contributing to level the responses to phosphate fertilization on soil that already has considerable reserves of the nutrient. Under these conditions, maintenance fertilization with organomineral fertilizers containing soluble or reactive phosphate had performance comparable to that of the triple superphosphate reference source.

Considering the productivity of the bean plant, and total export of $\mathrm{P}$ in the three crops, as indicators of the supply potential of phosphorus by the sources, the superiority of the organomineral fertilizer is highlighted combining poultry manure with super triple soluble phosphate.

\section{Conclusions}

The maintenance phosphate fertilization is necessary for increased productivity 
in the system of corn/soya/bean succession in soil with appropriate initial availability of P.

The use of organomineral sources combining poultry manure and soluble or reactive phosphates has technical efficiency comparable to that of the triple superphosphate in the fertilizer reference system.

The maintenance phosphate fertilization provided for corn presents enough residual effect to meet the nutritional demand of subsequent crops of beans and soy.

The bean plant expresses linear gain in productivity with the increase in the supply of $\mathrm{P}$ and differentiated response to the nutrient sources. For this culture, the organomineral fertilizer based on poultry manure and triple superphosphate has superior performance to that of other sources.

\section{References}

[1] Lana, M.D.C., Rampim, L. and Vargas, G. (2014) Adubação fosfatada no milho com fertilizante organomineral em latossolo vermelho eutroférrico. [Phosphate Fertilation on Corn with Organomineral Fertilizer in Oxisoil.] Global Science and Technology, 7, 26-36. https://doi.org/10.14688/1984-3801/gst.v7n1p26-36 http://rv.ifgoiano.edu.br/periodicos/index.php/gst/article/view/569

[2] Castro, S.H., Reis, R.P. and Lima, A.L.R. (2006) Custos de produção da sojacultivada sob sistema de plantiodireto: estudo de multicasos no oeste da Bahia. [Production Costs for Soybean under Systems of Direct Planting: Multicase Study in the West Region of the State of Bahia, Brazil.] Ciência e Agrotecnologia, 30, 1146-1153. https://doi.org/10.1590/S1413-70542006000600017 http://www.scielo.br/scielo.php?script=sci_arttext\&pid=S1413-70542006000600017

[3] Dos Santos, G., De Moraes, J.M.M. and Nussio, L.G. (2017) Custo e análise de sensibilidadenaprodução de silagem. [Cost and Sensitivity Analysis in the Production of Silage.] RevistaiPecege, 3, 39-48. https://revista.ipecege.org.br/Revista/article/view/100

[4] Silva, T.R., Menezes, J.F., Simon, G.A., de Assis, R.L., Catarina, J.D.L. and Gomes, G.V. (2011) Cultivo do milho e disponibilidade de P sob adubação com cama-de-frango. [Corn Cultivation and Availability of Phosphorus under Fertilization with Chicken Manure.] RevistaBrasileira de EngenhariaAgrícola e Ambiental, 15, 903-911. https://doi.org/10.1590/S1415-43662011000900005 http://www.scielo.br/pdf/rbeaa/v15n9/05.pdf

[5] Abpa (2016) Associaçãobrasileira de proteína animal. [Brazilian Association of Animal Protein.]

http://www.bpa-br.com.br/storage/files/versao_final_para_envio_digital_1925a_fin al_abpa_relatorio_anual_2016_portugues_web1.pdf

[6] Benites, V. (2011) Produção de fertilizantes organominerais utilizandoresíduos orgânicos de sistemas de produção animal: Umaalternativa paraagregação de valor aosresíduos e redução do impactoambiental. Embrapa Solos-SociedadeBrasileira dos Especialistasem Resíduos das Produções Agropecuária e Agroindustrial. [Production of Organomineral Fertilizers Using Organic Waste from Animal Production Systems: An Alternative to Aggregate Value to Waste and Reduce Environmental Impact. Embrapa Solos-Brazilian Society of Agricultural and Agroindustrial Producers Waste Specialists.] http://www.sbera.org.br 
[7] Novais, R.F., Smyth, T.J. and Nunes, F.N. (2007) Phosphor. In: Novais, R.F., Alvarez V.V.H., Barros, N.F., Fontes, R.L., Cantarutti, R.B. and Neves, J.C.L., Eds., Soil Fertility, SBCS, Viçosa, 471-550.

[8] Resende, A.V., Neto, A.E.F., Alves, V.M.C., Muniz, J.A., Curi, N., Faquin, V. and Carneiro, L.F. (2006) Fontes e modos de aplicação de fósforopara o milhoem solo cultivado da região do cerrado. [Phosphorus Sources and Application Methods for Maize in Soil of the Cerrado Region.] RevistaBrasileira de Ciência do Solo, 30, 453-456. https://doi.org/10.1590/S0100-06832006000300007 http://www.scielo.br/pdf/rbcs/v30n3/31212.pdf

[9] Frandoloso, J.F., Lana, M.C., Fontaniva, S. and Czycza, R.V. (2010) Eficiência de adubos fosfatados associados ao enxofre elementar na cultura do milho. [Efficiency of Phosphate-Fertilizers Associated with Elemental Sulfur in Corn.] Revista Ceres, 57, 686-694.

http://www.scielo.br/scielo.php?pid=S0034-737X2010000500019\&script=sci_abstra ct\&tlng=pt

[10] Kiehl, E.J. (2013) Fertilizantesorganominerais. [Organomineral Fertilizers.] 5th Edition, Editora Degaspari, Piracicaba.

[11] Silva, C. (2009) Manual de análisesquímicas de solos, plantas e fertilizantes. [Manual of Chemical Analyzes of Soils, Plants and Fertilizers.] 2nd Edition, Embrapa Informação Tecnológica, Brasília.

http://livraria.sct.embrapa.br/liv_resumos/pdf/00083136.pdf

[12] Malavolta, E., Vitti, G.C. and Oliveira, S.A. (1997) Avaliação do estadonutricional das plantas: Princípios e aplicações. [Evaluation of the Nutritional Status of Plants: Principles and Applications.] Piracicaba, Potafos.

[13] Ferreira, D.F. (2011) Sisvar: A Computer Statistical Analysis System. Ciência e Agrotecnologia, 35, 1039-1042. https://doi.org/10.1590/S1413-70542011000600001

[14] Simonete, M.A., Ernani, P.R., Moro, L., Gandra, C.F.A.T. and Gatiboni, L.C. (2015) Eficiência de Métodos analíticos na Predição da disponibilidade de fósforo para arroz irrigado em solos catarinenses. [Effectiveness of Chemical Methods in Predicting Phosphorus Availability to Flood Irrigated Rice in Soils of Santa Catarina State, Brazil.] Revista Brasileira de Ciência do Solo, 39, 1151-1160. http://www.redalyc.org/articulo.oa?id=180241055022

[15] Freitas, I.F.D., Novais, R.F., Villani, E.M.D.A. and Novais, S.V. (2013) Phosphorus Extracted by Ion Exchange Resins and Mehlich-1 from Oxisols (Latosols) Treated with Different Phosphorus Rates and Sources for Varied Soil-Source Contact Periods. Revista Brasileira de Ciência do Solo, 37, 667-677.

http://www.scielo.br/scielo.php?pid=S0100-06832013000300013andscript=sci_arttext https://doi.org/10.1590/S0100-06832013000300013

[16] Gonçalves, G.K., Bortolon, L., Meurer, E.J., Gonçalves, D.R.N., de Sousa, R.O., and Fagundes, S.M. (2012) Extratores de fósforopara o arrozirrigadoem solos adubados com fosfato natural reativo. [Phosphorus Extractors for Irrigated Rice on Soils under Reactive Phosphate Fertilization.] Revista de Ciências Agroveterinárias, 11, 196-204. http://revistas.bvs-vet.org.br/rca/article/view/34292

[17] Souza, R.M., Sobral, L.F., Viégas, P.R.A., de Oliveira Junior, A. and Carvalho, M.D.C.S. (2014) Eficiênciaagronômica de fosfatos de rochaem solo com elevadoteor de cálciotrocável. [Agronomic Efficiency of Rock Phosphates in a Soil with High Exchangeable Calcium Content.] Revista Brasileira de Ciência do Solo, 38, 1816-1826. http://www.scielo.br/scielo.php?pid=S0100-06832014000600016andscript=sci_abstr $\underline{\text { actandtlng }=p t}$ 
[18] Gatiboni, L.C., Kaminski, J., Rheinheimer, D.S. and Saggin, A. (2002) Quantificação do fosforo disponível por extrações sucessivas com diferentes extratores em latossolo vermelho distroférrico. [Quantification of Available Phosphorus by Successive Extractions with Different Methods in a Rhodic Hapludox.] Revista Brasileira de Ciência do Solo, 26, 1023-1029. https://doi.org/10.1590/S0100-06832002000400020

[19] Sousa, D.M.G. and Lobato, E. (2014) Cerrado: Correção do solo e adubação. [Cerrado: Soil Correction and Fertilization.] Embrapa Cerrados, Planaltina.

[20] Ourives, O.E.A., Souza, G.M., Tiritan, C.S. and Santos, D.H. (2010) Fertilizante organic como fonte de fósforo no cultivo inicial de Brachiaria brizantha cv. Marandú. [Organic Fertilizer as Phosphorus Supplier for Brachiaria brizantha cv. Marandú.] Pesquisa Agropecuária Tropical (Agricultural Research in the Tropics), 40, 126-132. https://www.revistas.ufg.br/pat/article/view/5138

[21] Ambrosano, E.J., Tanaka, R.T., Mascarenhas, H.A.A., Raij, B.V., Quaggio, J.A. and Cantarella, H. (1996) Leguminosas e oleaginosas. [Oil and Legume Crops.] In: Raij, B.V., Cantarella, H., Quaggio, J.A. and Furlani, A.M.C., Eds., Recomendaçóes de adubação e calagempara o estado de São Paulo [Recommendations of Fertilization and Liming for the State of São Paulo.], Instituto Agronômico e Fundação IAC, Campinas, 187-203.

[22] EmbrapaSoja (2013) Tecnologias de produção de soja-Região Central do Brasil, 2014. [Soya Production Technologies-Central Region of Brazil.] EmbrapaSoja, Londrina.

http://ainfo.cnptia.embrapa.br/digital/bitstream/item/95489/1/SP-16-online.pdf

[23] Conab (2016) Companhia Nacional de Abastecimento. Acompanhamento da safraBrasileira: Grãos, decimolevantamentojulho 2016. [National Supply Company. Follow-Up of the Brazilian Harvest: Grains, Tenth Survey July 2016.] http://www.conab.gov.br/OlalaCMS/uploads/arquivos/16_07_29_15_12_51_boleti m_graos_julho_2016.pdf

[24] Ramos, S.J., Faquin, V., Rodrigues, C.R., Silva, C.A., Ávila, F.W. and Sampaio, R.A. (2010) Utilização de fósforo e produção do feijoeiro: Influência de gramíneas forrageiras e fontes de fósforo. [Phosphorus Acquisition and Yield of Common Bean: Influence of Forage Grasses and Phosphorus Sources.] Revista Brasileira de Ciência do Solo, 34, 89-96.

http://www.scielo.br/scielo.php?pid=S0100-06832010000100009andscript=sci_abstr actandtlng=pt

[25] Borges, R.E., Menezes, J.F.S., Simon, G.A. and Benites, V. (2015) Eficiência da adubação com organomineral naprodutividade de soja e milho. [Fertilization Efficiency with Organo-Mineral on Productivity of Soybean and Corn.] Global Science and Technology, 8, 177-184. https://doi.org/10.14688/1984-3801/gst.v8n1p177-184 http://rioverde.ifgoiano.edu.br/periodicos/index.php/gst/index

[26] iritan, C.S., Santos, D.H., Bordini, R.A., Foloni, J.S.S. and Onishi, R.Y. (2011) Produção de matériaseca de milhoemfunção da adubaçãofosfatada mineral e organomineral. [Dry Matter Accumulation in Corn as a Function of Phosphorus Fertilization Mineral and Organomineral.] In Colloquium Agrariae, 6, 1-7.

http://agris.fao.org/agris-search/search.do?recordID=BR2013800115 https://doi.org/10.5747/ca.2010.v06.n1.a044

[27] Lacerda, J.J.J., de Resende, Á.V., Neto, A.E.F., Hickmann, C. and da Conceição, O.P. (2015) Adubação, produtividade e rentabilidade da rotação entre soja e milhoem solo com fertilidadeconstruída. [Fertilization, Grain Yield and Profitability of the Rotation between Soybean and Corn in Soil with Improved Fertility.] Pesquisa Agropecuária Brasileira, 50, 769-778. http://www.scielo.br/pdf/pab/v50n9/1678-3921-pab-50-09-00769.pdf 
[28] Carvalho, J.J., Bastos, A.V.S., Saad, J.C.C., Naves, S.S., Soares, F.A.L. and Vidal, V.M. (2014) Teor e acúmulo de nutrients em grãos de feijão comum em semeadura direta, sob déficit hídrico. [Nutrient Content and Accumulation in Common Bean Grains under No-Tillage, under Water Deficit.] Irriga, 1, 104-117.

http://revistas.fca.unesp.br/index.php/irriga/article/view/1686

https://doi.org/10.15809/irriga.2014v1n1p104

\section{Scientific Research Publishing}

Submit or recommend next manuscript to SCIRP and we will provide best service for you:

Accepting pre-submission inquiries through Email, Facebook, LinkedIn, Twitter, etc. A wide selection of journals (inclusive of 9 subjects, more than 200 journals)

Providing 24-hour high-quality service

User-friendly online submission system

Fair and swift peer-review system

Efficient typesetting and proofreading procedure

Display of the result of downloads and visits, as well as the number of cited articles

Maximum dissemination of your research work

Submit your manuscript at: http://papersubmission.scirp.org/

Or contact ajps@scirp.org 